\title{
HUBUNGAN KOMPETENSI PEDAGOGIK DAN MOTIVASI MENGAJAR DENGAN PRODUKTIVITAS GURU IPA SMP NEGERI SE-KABUPATEN LAMPUNG TIMUR
}

\author{
Sulis tiyani \\ SMP Negeri 1 Bumi Agung Lampung Timur \\ E-mail: sulistiyani75@yahoo.co.id
}

\begin{abstract}
Professional teachers are teachers who have competence to support their tasks that teachers can achieve high productivity. Factors related to teacher's productivity include pedagogic competence and teaching motivation. The aims of this research are want to know: (1) relationship between pedago gic competence with productivity (2) relationship between teaching motivation with productivity (3) relationship between pedagogic competence and teaching motivation together with productivity. The population of this research were all science teachers those be civil servants at SMP in East Lampung District in the school year of 2013/2014 as many as 168 people, and samples 63 teachers. The instrument used was a questionnaire that had been tested for validity and reliability. The data analysis used was the technique of correlation and simple regression analysis on the first and second hypothesis testing, and regression analysis technique on the third hypothesis testing. Based on the theoretical studies and findings of data analysis both partially and simultaneously, it can be concluded that pedagogic competence and teaching motivation positively and significantly associated with productivity of Junior High School Science Teachers in East Lampung District. The benefits of this research as an input for principals and supervisors who act as a motivator, facilitator, and dynamisator to enhance the pedagogic competence and teaching motivation by providing opportunities to follow activities such as training, workshops, or seminars in order to increase productivity.
\end{abstract}

Kata Kunci: ko mpetensi pedagogik, motivasi mengajar, produktiv itas guru

Guru merupakan komponen paling menentukan dalam sistem pendidikan secara keseluruhan, yang harus mendapatkan perhatian sentral, pertama, dan utama. Guru memegang peran utama dalam pembangunan pendidikan, khususnya yang diselenggarakan secara formal di sekolah. Hal tersebut sesuai dengan Undang-undang No. 14 Tahun 2005 tentang Guru dan Dosen pada pasal 1 yaitu, guru adalah pendidik profesional dengan tugas utama mendidik, mengajar, membimbing, mengarahkan, melatih, menilai, dan mengevaluasi peserta didik pada pendidikan anak usia dini jalur pendidikan formal, pendidikan dasar, dan pendidikan menengah.

Selanjutnya menurut UU No. 14 Tahun 2005, tentang guru dan dosen pasal 4 diamanatkan bahwa guru sebagai agen pembelajaran berfungsi untuk meningkatkan mutu pendidikan nasional agar dapat melaksanakan fungsinya dengan baik, guru wajib untuk memiliki syarat tertentu, salah satu diantarannya adalah kompetensi. 
Guru yang profesional, adalah guru yang memiliki kompetensi yang dapat menunjang tugas-tugasnya yang meliputi kompetensi pedagogik, kompetensi profesional, kompetensi sosial, dan kompetensi kepribadian. Dengan memiliki kompetensikompetensi tersebut diharapkan guru mampu menciptakan suasana proses pembelajaran yang kondusif, aktif, kreatif, dan menyenangkan sehingga proses pembelajaran dapat dicapai secara optimal.

Kondisi ideal pendidikan yang bermutu, hingga saat ini belum dapat terwujud dengan baik, hal ini tidak terlepas dari kondisi sumber daya manusia terutama guru yang masih relatif rendah. Masih banyak guru yang belum mampu mengembangkan silabus dan RPP, belum mampu membuat LKS dan bahan ajar sendiri, dan penilaian yang diberikan hanya pada aspek kognitif saja. Fenomena tersebut juga terjadi pada guru-guru IPA SMP Negeri di Kabupaten Lampung Timur. Berdasarkan hasil prasurvei dari wawancara dengan beberapa guru IPA SMP Negeri di Kabupaten Lampung Timur dapat diketahui bahwa produktivitas guru IPA masih rendah.

Tenaga pendidik dalam hal ini adalah guru IPA SMP Negeri di Kabupaten Lampung Timur, harus memiliki kompetensi yang dapat menunjang tugas-tugasnya yang meliputi kompetensi pedagogik, kompetensi profesional, kompetensi sosial, dan kompetensi kepribadian. Dengan memiliki kompetensikompetensi tersebut diharapkan guru mampu menciptakan suasana proses pembelajaran yang kondusif, aktif, kreatif, dan menyenangkan sehingga proses pembelajaran dapat dicapai secara optimal dan guru mampu mengembangkan silabus, RPP, bahan ajar, media pembelajaran, LKS, dan alat penilaian sesuai tujuan dalam Kurikulum Tingkat Satuan Pendidikan (KTSP).

Produktivitas guru berdampak terhadap kualitas akademis maupun moral peserta didik. Bila produktivitas guru tinggi maka prestasi belajar peserta didik akan meningkat. Bisa diartikan bahwa produktivitas guru memiliki kontribusi dalam mencetak lulusan yang berkualitas dari segi akademis maupun moral sehingga mampu bersaing dalam era globalisasi saat ini. Untuk meningkatkan produktivitas guru diduga banyak faktor yang berkaitan dengan hal tersebut. Di antara faktor-faktor tersebut adalah faktor internal yang meliputi kompetensi pedagogik, motivasi mengajar, kreativitas guru, dan kedisiplinan mengajar. Selain faktor internal tersebut, diduga pula terdapat faktor eksternal yang menentukan atau berkaitan dengan produktivitas guru, antara lain kepemimpinan sekolah, iklim sekolah, dan lingkungan sekolah.

Kompetensi pedagogik dan motivasi mengajar diduga sebagai faktor yang dominan dan memiliki kontribusi dalam meningkatkan produktivitas guru. Hal ini karena kompetensi pedagogik akan memberikan pengaruh yang kuat terhadap kinerja guru dalam melaksanakan tugasnya. Sedangkan motivasi mengajar membuat gairah kerja yang kondusif bagi guru dalam melaksanakan tugasnya dengan baik dan optimal.

\section{METODE}

Rancangan penelitian yang digunakan yaitu penelitian kuantitatif yang bersifat korelasional, yaitu dengan melihat hubungan antara masing-masing variabel $\mathrm{X}$ dengan $\mathrm{Y}$. Sifat hubungan antara variabel bebas dan variabel terikat pada model regresi 
harus merupakan hubungan sebab akibat karena tujuan penggunaan model regresi ini adalah untuk mengetahui sejauhmana hubungan antara variabel bebas dengan variabel terikat.

Pengolahan data dalam penelitian ini dilakukan dengan teknik analisis deskriptif dan uji hipotesis dengan analisis korelasional. Sebelum melaksanakan analisis korelasional, terlebih dahulu dilakukan uji normalitas, uji homogenitas, dan uji linearitas.

Penelitian ini menggunakan teknik analisis korelasi dan regresi. Untuk mencari hubungan $\mathrm{X}_{1}$ dengan $\mathrm{Y}$,
$\mathrm{X}_{2}$ dengan $\mathrm{Y}$, menggunakan analisis korelasi dan regresi sederhana. Sedangkan untuk mencari hubungan $\mathrm{X}_{1}$ dan $\mathrm{X}_{2}$ secara bersama-sama dengan $\mathrm{Y}$ menggunakan analisis regresi berganda.

Variabel yang dianalisis dalam penelitian ini ada tiga, yakni variabel kompetensi pedagogik, variabel motivasi mengajar, dan variabel produktivitas guru. Setelah data diperoleh dari instrumen data yang valid, selanjutnya dilakukan pengujian hipotesis, sehingga diperoleh keputusan dan kesimpulan.

\section{HASIL}

\section{Uji Normalitas}

\begin{tabular}{lcccc}
\hline \multicolumn{1}{c}{ Statistik } & $\begin{array}{c}\text { Kompetensi } \\
\text { Pedagogik }\end{array}$ & $\begin{array}{c}\text { Motivasi } \\
\text { Mengajar }\end{array}$ & $\begin{array}{c}\text { Produktivitas } \\
\text { Guru }\end{array}$ & Keterangan \\
\hline $\begin{array}{l}\text { Kolmogorov- } \\
\begin{array}{l}\text { Smirnov Z } \\
\text { Asymp. Sig. (2- } \\
\text { tailed) }\end{array}\end{array}$ & 0.738 & 0.472 & 1.147 & Distribusi \\
normal
\end{tabular}

Kriteria Uji: Terima $\mathrm{H}_{0}$ jika Sig. > 0,05, berarti data berdistribusi normal. Dalam harga lain $\mathrm{H}_{0}$ ditolak, berarti data tidak berdistribusi normal.

\section{Uji Homogenitas}

Berdasarkan hasil olah data SPSS versi 16.00 pada uji homogenitas diperoleh nilai signifikansi probabiliti based on mean sebesar 0,062 .

Kriteria Uji: terima $\mathrm{H}_{0}$ jika Sig. > 0,05, berarti data memiliki variansi yang homogen. Dalam harga lain $\mathrm{H}_{0}$ ditolak, berarti data tidak memiliki variansi yang homogen. Dengan demikian dapat disimpulkan bahwa distribusi data dari jawaban instrumen berasal dari sampel yang homogen.

3. Uji Linieritas

\begin{tabular}{cccc}
\hline Hubungan Variabel & F & Sig & Keterangan \\
\hline $\mathrm{X}_{1}$ dengan $\mathrm{Y}$ & 1,194 & 0,307 & Linier \\
$\mathrm{X}_{2}$ dengan $\mathrm{Y}$ & 1,229 & 0,284 & Linier \\
\hline
\end{tabular}

Kriteria Uji: Terima $\mathrm{H}_{0}$ jika Sig. $>0,05$, berarti persamaan regresi $\mathrm{Y}$ atas $\mathrm{X}$ linier. Dalam harga lain $\mathrm{H}_{0}$ ditolak, berarti persamaan regresi $\mathrm{Y}$ atas $\mathrm{X}$ tidak linier.

\section{Hipotesis Statistik Koefisien Korelasi Nihil}

\begin{tabular}{cccc}
\hline Korelasi & $\begin{array}{c}\text { Koefisien } \\
\text { Korelasi }\end{array}$ & Sig. & Kesimpulan \\
\hline $\mathrm{r}_{\mathrm{y} 1}$ & 0,387 & 0,001 & Koefisien kore lasi berarti \\
\hline $\mathrm{r}_{\mathrm{y} 2}$ & 0,370 & 0,001 & Koefisien kore lasi berarti \\
\hline
\end{tabular}


Kriteria Uji: Terima $\mathrm{H}_{0}$ jika Sig. $>0,05$, berarti koefisien korelasi tidak berarti. Dalam harga lain $\mathrm{H}_{0}$ ditolak, berarti koefisien korelasi berarti.

\section{Hipotesis Statistik Keberartian Regresi}

\begin{tabular}{lccc}
\hline \multicolumn{1}{c}{ Persamaan Regresi } & F hit & Sig. & Kesimpulan \\
\hline$\hat{Y}=a+b X_{1}$ & 10,768 & 0,002 & $\begin{array}{c}\text { Persamaan regresi } Y \\
\text { atas } \mathrm{X}_{1} \text { berarti }\end{array}$ \\
$\hat{\mathrm{Y}}=39,660+0,322 \mathrm{X}_{1}$ & & & \\
\hline$\hat{\mathrm{Y}}=\mathrm{a}+\mathrm{b} \mathrm{X}_{2}$ & 9,659 & 0,003 & $\begin{array}{c}\text { Persamaan regresi } \mathrm{Y} \\
\text { atas } \mathrm{X}_{2} \text { berarti }\end{array}$ \\
$\hat{\mathrm{Y}}=51,493+0,277 \mathrm{X}_{2}$ & & & \\
\hline$\hat{Y}=\mathrm{a}_{0}+\mathrm{a}_{1} \mathrm{X}_{1}+\mathrm{a}_{2} \mathrm{X}_{2}$ & & & Persamaan regresi $\mathrm{Y}$ \\
$\hat{\mathrm{Y}}=23,348+0,292 \mathrm{X}_{1}+0,248 \mathrm{X}_{2}$ & & 0,000 & \\
& & & atas $\mathrm{X}_{1}$ dan $\mathrm{X}_{2}$ berarti
\end{tabular}

Kriteria Uji: Terima $\mathrm{H}_{0}$ jika Sig. > 0,05, berarti persamaan regresi $\mathrm{Y}$ atas $\mathrm{X}$ tidak berarti. Dalam harga lain $\mathrm{H}_{0}$ ditolak, berarti persamaan regresi $\mathrm{Y}$ atas $\mathrm{X}$ berarti.

\section{PEMBAHASAN}

\section{Hubungan Kompetensi \\ Pedagogik $\left(\mathrm{X}_{1}\right)$ dengan \\ Produktivitas Guru (Y)}

Berdasarkan hasil pengujian hipotesis pertama diperoleh nilai koefisien korelasi sebesar 0,387 dengan indeks determinasi sebesar 0,15 , artinya kompetensi pedagogik memberikan kontribusi pada produktivitas guru sebesar $15 \%$ dengan model regresi $\hat{Y}=39,660+0,322 X_{1}$, dengan demikian hubungan kompetensi pedagogik dengan produktivitas guru adalah positif dan berarti.

bahwa kompetensi pedagogik mempunyai hubungan yang positif dan berarti dengan produktivitas guru. Temuan ini mengimplikasikan bahwa kompetensi pedagogik yang efektif merupakan suatu kondisi yang harus diwujudkan sebagai usaha untuk meningkatkan produktivitas guru. Semakin tinggi kompetensi pedagogik guru, semakin tinggi produktivitas guru. Begitu juga sebaliknya, ketidakefektifan kompetensi pedagogik seorang guru juga berdampak pada menurunnya produktivitas guru.

Hasil penelitian ini mendukung hasil penelitian sebelumnya yang dilakukan oleh Darni (2012) yang menyimpulkan bahwa ada hubungan antara kompetensi pedagogis dengan kinerja guru PAI, dan Sari (2012) yang menyimpulkan bahwa ada korelasi yang signifikan antara kompetensi pedagogik dengan kinerja guru.

Kompetensi pedagogik yang efektif, memberi pengaruh pada aktivitas guru dalam melaksanakan tugasnya. Keadaan ini akan terus mendorong guru untuk melaksanakan tugas dengan lebih baik dalam rangka mencapai tujuan organisasi yang telah ditetapkan. Melalui kompetensi pedagogik, guru dituntut mampu menciptakan situasi pembelajaran yang efektif dalam mencapai tujuan yang ditentukan. Sebagaimana penjelasan Hakim (2008) dengan pendapat bahwa kompetensi pedagogik adalah kompetensi dalam mengelola pembelajaran, diantaranya ditandai dengan kompetensi guru 
mengembangkan situasi pembelajaran yang utuh, menyeluruh, dinamis, dan bermakna sesuai dengan harapan dan kompetensi, serta kebutuhan dan kesiapan siswa.

Berdasarkan pendapat tersebut, kegiatan mengajar yang dilaksanakan secara profesional sangat dibutuhkan oleh setiap guru untuk menghasilkan produktivitas guru yang maksimal. Guru perlu menyusun perencanaan pembelajaran secara sistematis, bahan pengajaran harus dikuasai oleh guru sehingga peserta didik dapat menyerap materi yang disampaikan. Hal ini cukup sulit dirasakan oleh guru karena peserta didik bukan hanya sebagai individu dengan segala keunikannya tetapi juga sebagai makhluk sosial dengan latar belakang yang berlainan. Guru mempunyai tugas yang cukup berat dalam mengelola kelas dengan baik. Kegagalan guru dalam mengelola kelas dapat menyebabkan tujuan pembelajaran sulit tercapai. Sebagaimana yang diungkapkan Sukmadinata (dalam Rusman, 2011) bahwa pada tahap perencanaan pembelajaran, guru dituntut untuk membuat program pembelajaran.

Kesulitan peserta didik dalam memahami konsep dan prinsip tertentu dapat diatasi dengan media dan alat bantu. Dengan memanfaatkan media dan alat bantu dapat membuat proses pembelajaran lebih efektif dan menarik. Alat bantu dapat mewakili sesuatu yang tidak dapat disampaikan guru melalui kata-kata. Hal ini senada dengan pendapat Ibrahim (dalam Rusman, 2011) bahwa media dapat digunakan untuk menyalurkan materi pembelajaran, merangsang pikiran, perasaan, perhatian, dan kemampuan siswa sehingga dapat mendorong proses pembelajaran.

Peningkatan kompetensi pedagogik merupakan hal penting yang harus diwujudkan, karena hal ini berdampak pada tingkat produktivitas guru. Implikasinya dalam dunia pendidikan adalah guru yang profesional harus mengusahakan dengan baik terwujudnya kompetensi pedagogik yang efektif. Kompetensi pedagogik yang efektif ini dapat meningkatkan produktivitas guru yang pada akhirnya dapat mewujudkan keefektifan pendidkan. Pendidikan yang efektif, dapat melaksanakan program-program pembelajaran dengan baik sehingga dapat mencapai tujuan pendidkan yang baik, efektif dan efisien. Oleh karenanya, peningkatan keefektifan kompetensi pedagogik ini menjadi faktor penting dalam upaya meningkatkan produktivitas guru dalam rangka meningkatkan kualitas pendidikan di SMP Negeri seKabupaten Lampung Timur.

\section{Hubungan Motivasi Mengajar $\left(X_{2}\right)$ dengan Produktivitas Guru (Y)}

Berdasarkan hasil pengujian hipotesis kedua diperoleh nilai koefisien korelasi sebesar 0,370 dengan indeks determinasi sebesar 0,137, artinya motivasi mengajar memberikan kontribusi pada produktivitas guru sebesar $13,7 \%$ dengan model regresi $\hat{Y}$ $=51,493+0,277 \mathrm{X}_{2}$, dengan demikian hubungan motivasi mengajar dengan produktivitas guru adalah positif dan berarti.

Hasil analisis menunjukkan bahwa terdapat hubungan positif dan berarti antara motivasi mengajar dengan produktivitas guru. Hasil ini menunjukkan bahwa motivasi memberikan kontribusi yang penting kaitannya dengan usahameningkatkan produktivitas guru. Hal ini mengimplikasikan bahwa pemberian motivasi merupakan usaha yang harus terus ditingkatkan agar produktivitas 
guru juga terus mengalami peningkatan.

Guru yang memiliki motivasi tinggi dalam melaksanakan pekerjaannya, menunjukkan bahwa guru tersebut memiliki kinerja yang tinggi. Begitu juga sebaliknya, guru yang memiliki motivasi yang rendah, menunjukkan bahwa guru tersebut memiliki kinerja yang rendah. Hasil penelitian ini mendukung hasil penelitian sebelumnya yang dilakukan oleh Darni (2012) yang menyimpulkan bahwa ada hubungan antara motivasi mengajar dengan kinerja guru PAI, Gayatri (2010) yang menyimpulkan ada pengaruh yang positif dan signifikan antara motivasi kerja, kompetensi guru, dan kepuasan guru terhadap kinerja guru, Sriyono (2010) yang menyimpulkan bahwa ada pengaruh yang signifikan antara motivasi kerja guru, pengalaman kerja guru, dan profesionalisme guru terhadap kinerja guru. Hal ini juga senada dengan penjelasan Gibson (dalam Uno, 2008) dengan pendapat bahwa motivasi seorang guru akan berbeda dengan motivasi guru lainnya, dan perbedaan motivasi ini akan menimbulkan kinerja yang dihasilkan seorang guru.

Berdasarkan pendapat tersebut dapat dijelaskan bahwa produktivitas guru itu dipengaruhi oleh tingkat motivasi guru. Semakin tinggi tingkat motivasi mengajar guru akan berdampak pada meningkatnya produktivitas guru. Hal ini menunjukkan bahwa hal penting yang harus dilakukan adalah mengusahakan agar tingkat motivasi mengajar guru selalu mengalami peningkatan. Usaha peningkatan motivasi ini penting dilakukan sebagai usaha untuk terus meningkatkan kinerja seseorang. Motivasi yang terus meningkat, berdampak pada meningkatnya kinerja dan kondisi ini sudah barang tentu berdampak pada meningkatnya keefektifan organisasi dalam mencapai tujuan yang telah ditentukan.

Produktivitas guru akan terus mengalami peningkatan manakala motivasi mengajar dalam diri guru tersebut juga mengalami peningkatan. Setiap aktivitas manusia baik fisik maupun psikis sangat membutuhkan adanya motivasi. Hal ini sesuai pendapat McClelland (dalam Thoha, 2009) bahwa seseorang dianggap mempunyai motivasi untuk berprestasi jika ia mempunyai keinginan untuk melakukan suatu karya yang berprestasi lebih dari prestasi karya orang lain. Motivasi mengajar itu juga berpengaruh pada ketekunan seseorang dalam melaksanakan pekerjaannya. Motivasi yang ada dalam diri seseorang akan mendorong seseorang tersebut untuk tekun dalam melaksanakan pekerjaannya. Ketekunan yang ditampakkan tersebut bukanlah karena adanya pengawasan dari pimpinan, akan tetapi karena adanya motivasi yang tinggi dalam pribadi seseorang tersebut. Ketekunan ini pulalah yang membawa seseorang untuk melaksanakan pekerjaannya dengan sebaik-baiknya. Kondisi ini bermuara pada tercapainya tujuan organisasi secara efektif dan efisien.

\section{Hubungan Kompetensi Pedagogik $\left(\mathrm{X}_{1}\right)$ dan Motivasi Mengajar $\left(\mathrm{X}_{2}\right)$ dengan Produktivitas Guru (Y)}

Berdasarkan hasil pengujian hipotesis ketiga diperoleh indeks determinasi sebesar 0,259, artinya kompetensi pedagogik dan motivasi mengajar memberikan kontribusi pada produktivitas guru sebesar 25,9\% dengan model regresi $\hat{Y}=23,348+$ $0,292 X_{1}+0,248 X_{2}$, dengan demikian hubungan kompetensi pedagogik dan 
motivasi mengajar dengan produktivitas guru adalah sangat berarti. Semakin tinggi nilai $\mathrm{X}_{1}$ dan $\mathrm{X}_{2}$ maka semakin tinggi nilai $Y$. Guru yang memiliki kompetensi pedagogik dan motivasi mengajar yang tinggi maka akan meningkatkan produktivitas guru.

Kompetensi pedagogik dan motivasi yang tinggi yang dimiliki oleh guru dapat meningkatkan produktivitas guru. Guru yang bekerja dengan didukung oleh motivasi mengajar yang tinggi maka kompetensi pedagogiknya semakin baik sehingga produktivitas guru juga meningkat. Dalam melaksanakan tugas mengajar, guru harus berusaha untuk menerapkan kompetensi pedagogik yang dimilikinya yang didukung dengan motivasi mengajar yang tinggi sehingga mampu meningkatkan produktivitas guru. Hal ini sesuai pendapat Mangkunegara (2000) bahwa faktor yang mempengaruhi pencapaian kinerja adalah faktor kemampuan dan faktor motivasi.

Kompetensi pedagogik pada intinya adalah kompetensi guru dalam berinteraksi dengan siswa dalam pembelajaran dengan baik. Interaksi yang dimaksud berupa tampilan guru dalam menyajikan materi dilandasi kedekatan komunikasi dengan siswa, kompetensi dalam menjelaskan materi, dan kompetensi lainnya. Banyak kegiatan yang harus dilakukan guru dari penyusunan perencanaan pembelajaran sampai tahap evaluasi. Masing-masing tahap kegiatan harus dilaksanakan secara sistematis dengan memanfaatkan sarana dan sumber bahan yang tepat, sehingga setiap tahapan pembelajaran dapat dicapai dengan optimal.

Setiap tahapan yang dilakukan dengan cermat serta berulang-ulang, maka akan membentuk pengalaman sekaligus membentuk kemampuan seseorang atas pekerjaan tertentu termasuk dibidang pengajaran. Implikasi lanjut dari tuntutan pemilikan kemampuan pedagogis itu karena pentingnya merangsang mentalitas guru sebagai tenaga yang bekerja dibidang pendidikan. Mengajar yang bertujuan untuk mencapai peningkatan mutu pendidikan di sekolah harus diupayakan mampu mewujudkan kinerja yang baik. Hal ini sesuai pendapat Danim (2003) bahwa fokus kerja guru harus berpihak pada upaya pencapaian tujuan. Menjalankan kegiatan pembelajaran bagi guru tidak boleh dipandang sebagai bentuk pekerjaan pada umumnya, tetapi lebih ditekankan pada pengabdian. Melalui sikap pengabdian yang sungguhsungguh diharapkan akan dicapai peningkatan kualitas pembelajaran sebagai indikator penting tercapainya peningkatan mutu pendidikan di sekolah.

\section{KESIMPULAN DAN SARAN Kesimpulan}

Berdasarkan kajian teoritik dan temuan hasil analisis data baik secara parsial dan simultan, maka dapat disimpulkan bahwa kompetensi pedagogik dan motivasi mengajar berhubungan secara positif dan berarti dengan produktivitas guru IPA khususnya pada SMP Negeri seKabupaten Lampung Timur.

Simpulan tersebut ditunjukkan dari temuan-temuan hasil analisis sebagai berikut:

1. Berdasarkan hasil pengujian hipotesis pertama diperoleh nilai koefisien korelasi sebesar 0,387 dengan indeks determinasi sebesar $0,15, \quad$ artinya kompetensi pedagogik memberikan kontribusi pada produktivitas guru sebesar $15 \%$ dengan model regresi $\hat{\mathrm{Y}}=$ 
$39,660+0,322 X_{1}$, sehingga terdapat hubungan yang positif dan signifikan antara kompetensi pedagogik dengan produktivitas guru IPA SMP Negeri seKabupaten Lampung Timur. Semakin tinggi kompetensi pedagogik yang dimiliki guru, produktivitas yang dihasilkan juga semakin meningkat.

2. Berdasarkan hasil pengujian hipotesis kedua diperoleh nilai koefisien korelasi sebesar 0,370 dengan indeks determinasi sebesar 0,137 , artinya motivasi mengajar memberikan kontribusi pada produktivitas guru sebesar $13,7 \%$ dengan model regresi $\hat{\mathrm{Y}}=51,493$ $+0,277 \mathrm{X}_{2}$, sehingga terdapat hubungan yang positif dan signifikan antara motivasi mengajar dengan produktivitas guru IPA SMP Negeri seKabupaten Lampung Timur. Semakin tinggi motivasi mengajar yang dimiliki guru, maka semakin tinggi pula produktivitas guru yang dihasilkan.

3. Berdasarkan hasil pengujian hipotesis ketiga diperoleh indeks determinasi sebesar 0,259, artinya kompetensi pedagogik dan motivasi mengajar memberikan kontribusi pada produktivitas guru sebesar 25,9\% dengan model regresi $\hat{Y}=23,348+0,292 \mathrm{X}_{1}+$ $0,248 \mathrm{X}_{2}$, sehingga terdapat hubungan yang berarti antara kompetensi pedagogik dan motivasi mengajar secara bersamasama dengan produktivitas guru IPA SMP Negeri se-Kabupaten Lampung Timur.'Semakin tinggi kompetensi dan motivasi seorang guru, semakin tinggi pula produktivitas guru yang dihasilkan.

\section{Saran}

Berdasarkan kesimpulan penelitian ini, maka dapat diberikan saran-saran kepada:

1. Kepala Sekolah, hendaknya kepala sekolah berusaha untuk meningkatkan pelaksanaan supervisi kelas sehingga kepala sekolah dapat memantapkan perannya sebagai motivator, fasilitator, dan dinamisator pelaksanaan pendidikan di sekolah, sehingga diharapkan dapat meningkatkan kompetensi guru yang diikuti dengan meningkatnya produktivitas guru.

2. Kepada para guru, agar berusaha meningkatkan produktivitasnya dengan cara membuat seperangkat alat pembelajaran yang meliputi program pembelajaran, RPP, dan analisis hasil ulangan, membuat karya pengembangan profesi yang meliputi karya ilmiah, bahan ajar, alat peraga dan media pembelajaran, serta keikutsertaan dalam forum ilmiah yang meliputi peran sebagai pemakalah dan peran sebagai peserta.

3. Kepada para pembaca dan peneliti selanjutnya agar dapat lebih banyak memperluas kajian tentang produktivitas guru dan fakta-fakta terkait yang tidak dibahas dalam penelitian ini.

\section{DAFTAR RUJUKAN}

Darni, A.S. 2012. Hubungan Antara Motivasi Mengajar dan Kompetensi Pedagogik dengan Kinerja Guru Pendidikan Agama Islam SD Negeri Kota Metro. Tesis tidak diterbitkan. Metro: Program Pasca Sarjana STAIN Jurai Siwo Metro.

Danim, S. 2003. Strategi Pembelajaran. Jakarta: Erlangga. 
Gayatri, A. D. 2010. Kontribusi Motivasi Kerja, Kompetensi Guru dan Kepuasan Guru terhadap Kinerja Guru Mata Pelajaran di SMA Negeri Kota Surakarta.

(http://etd.eprints.ums.ac.id/6859 ).

Hakim, L. 2008. Metode Pembelajaran. Jakarta: Intimedia

Mangkunegara, A. A. Anwar Prabu. 2000. Manajemen Sumber Daya Manusia. Bandung: Remaja Rosdakarya.

Rusman. 2011. Model-model Pembelajaran: Mengembangkan Profesionalisme Guru. Jakarta: Rajawali Pers.

Sari, N. 2012. Korelasi Antara Kompetensi Pedagogik dan Kreativitas Pembelajaran dengan Kinerja Guru di SMP seKecamatan Bangun Rejo Kabupaten Lampung Tengah. Tesis tidak diterbitkan. Metro: Program Pasca Sarjana STAIN Jurai Siwo Metro.

Sriyono. 2010. Pengaruh Motivasi Kerja Guru, Pengalaman Kerja Guru dan Profesionalisme Guru terhadap Kinerja Guru SMK Muhammadiyah se- Kabupaten Klaten.

(http://etd.eprints.ums.ac.id/6728 )

Thoha, M. 2009. Motivasi Teori dan Praktik. Jakarta: Rajawali.

Uno, H. B. 2008. Teori Motivasi. Jakarta: Erlangga. 